\title{
Caracterização fenotípica e genotípica de isolados de Ornithobacterium rhinotracheale do Brasil*
}

\author{
MARISA MACAGNAN
}

\author{
Cláudio Wageck Canal (Orientador - UFRGS)
}

Banca: Gertrudes Corção (UFRGS), Marisa da Costa (UFRGS), Marisa Ribeiro de Itapema Cardoso (UFRGS)

Ornithobacterium rhinotracheale é uma bactéria associada com doença respiratória, decréscimo no crescimento, condenação de carcaças e mortalidade em galinhas e perus. Esta bactéria tem sido isolada em vários países e, recentemente, foi isolada no Brasil pelo nosso grupo que também estabeleceu um protocolo de reação em cadeia da polimerase (PCR) para a sua detecção e identificação e determinou a prevalência de anticorpos contra esta bactéria em plantéis comerciais de frangos e de matrizes da Região Sul do Brasil. O presente trabalho teve o objetivo de caracterizar isolados de $O$. rhinotracheale através de sorotipificação, resistência a antimicrobianos e single-enzyme amplified fragment length polymorphism (SAFLP). Vinte e sete isolados foram compatíveis com esta espécie através de isolamento em ágar sangue com gentamicina, coloração de Gram, teste de aglutinação em lâmina e reação em cadeia da polimerase. Dezenove isolados foram classificados como sorotipo A, seis não puderam ser sorotipificados com o painel de soros existentes e dois pertenceram ao sorotipo C. Vinte e cinco isolados foram sensíveis à norfloxacina, amoxicilina, doxiciclina, lincomicina e cefalotina, dois isolados foram resistentes à neomicina e 18 foram resistentes à sulfametoxazol/trimetoprima. Na análise de SAFLP, 22 isolados apresentaram padrão idêntico e os cinco isolados restantes foram classificados em cinco padrões distintos. Os resultados da sorotipificação indicaram que o sorotipo A de O. rhinotracheale é predominante em criações comerciais no Brasil. Os isolados brasileiros foram sensíveis à maioria dos antimicrobianos testados. O poder discriminatório do teste de suscetibilidade a antimicrobianos foi maior do que a sorotipificação e SAFLP, porém o método de SAFLP gerou um maior número de padrões, sugerindo que possa ser utilizado como ferramenta em estudos epidemiológicos.

Descritores: Ornithobacterium rhinotracheale, galinha, doença respiratória, antimicrobianos, SAFLP, sorotipo.

Apresentada: 22 fevereiro 2006

"Dissertação de Mestrado n.425 (Especialidade: Sanidade Avícola). 50f. Programa de Pós-graduação em Ciências Veterinárias [www.ufrgs.br/ ppgcv], Faculdade de Veterinária - UFRGS, Porto Alegre/RS. CORRESPONDÊNCIA: M. Macagnan [mmacagnan@yahoo.com.br] \& C.W. Canal [claudio.canal@ufrgs.br]. 


\title{
Phenotypic and genotypic characterization of Ornithobacterium rhinotracheale isolated from Brazil ${ }^{* *}$
}

\begin{abstract}
MARISA MACAGNAN
Cláudio Wageck Canal (Adviser - UFRGS)

Committee: Gertrudes Corção (UFRGS), Marisa da Costa (UFRGS), Marisa Ribeiro de Itapema Cardoso (UFRGS)

Ornithobacterium rhinotracheale is a bacteria associated with respiratory disease, growth retardation, condemnation of carcases and mortality in chickens and turkeys. It has been isolated in several countries and, recently, our group has isolated it,established a polymerase chain reaction (PCR) protocol to detect and to identify and have determined the prevalence of antibodies against this bacteria in broilers and breeders from Southern Brazil. The aim of this study was to characterize isolates of $O$. rhinotracheale through serotyping, antimicrobial resistance and single-enzyme amplified fragment length polymorphism (SAFLP). Twenty-seven isolates were compatible with $O$. rhinotracheale through isolation on blood agar with gentamicin, Gram staining, slide agglutination test and PCR. Nineteen isolates were classified as serotype A, six isolates could not be serotyped with the available panel of antisera and two isolates belonged to serotype $\mathrm{C}$. Twenty-five isolates were sensitive to norfloxacin, amoxicillin, doxycycline, lincomycin and cefalotine, two isolates were resistant to neomycin and eighteen were resistant to sulphamethoxazole-trimethoprim. In the analysis of SAFLP, twenty-two isolates displayed one identical pattern and the five remaining isolates were classified in five distinct patterns. Results of this study indicate that serotype A of $O$. rhinotracheale predominates in commercial chickens in Brazil. Brazilian isolates were sensitive to most of the antimicrobials tested. The discriminatory power of antimicrobial susceptibility testing was higher than the serotyping and SAFLP, but the latter method generated a higher number of patterns, suggesting that it can be a useful tool in $O$. rhinotracheale epidemiological studies.
\end{abstract}

Key words: Ornithobacterium rhinotracheale, chicken, respiratory disease, antimicrobial, SAFLP, serotype. 